Covid-19 en Turquía: aburrimiento en el ocio, resiliencia psicológica, actividad física y estado emocional

\title{
Covid-19 in Turkey: Leisure boredom, psychological resilience, physical activity and emotional state
}

Mücahit Dursun.

Faculty of Sport Sciences, Gazi University, Ankara, Turkey. mucahitdursun1903@gmail.com

Yunus Emre Yarayan.

Faculty of Sport Sciences, Gazi University, Ankara, Turkey. yunus.emre.yarayan@gmail.com

Çağrı Arı

Faculty of Sport Sciences, Muş Alparslan University, Muş, Turkey cagri.ari1989@gmail.com

Cihan Ulun.

Faculty of Sport Sciences, Gazi University, Ankara, Turkey. cihanulun06@gmail.com

Selda Kocamaz Adaş.

Faculty of Sport Sciences, Gazi University, Ankara, Turkey. seldakocamazadas@gmail.com

\section{RESUMEN.}

Esta investigación se realizó en el proceso de cuarentena implementado en el brote de CoViD-19 para examinar la relación entre la percepción del aburrimiento de los individuos en los momentos de ocio y los niveles de resiliencia psicológica, y describir las actividades de ocio de los individuos, la participación en la actividad física y estado emocional. En consecuencia, participaron un total de 2214 personas voluntarias que vivían en Turquía, con 909 hombres $(41,1 \%)\left(\bar{X}_{\text {edad }}=33,83 \pm 10,73\right)$ y 1305 mujeres $(58,9 \%)\left(\bar{X}_{\text {edad }}=32,41 \pm 10,02\right)$. En el ámbito del estudio, se recogió información sobre variables demográficas, actividad física y estado emocional con el formulario creado por los investigadores. En el estudio, la "Escala de aburrimiento del ocio" y la "Escala de resiliencia psicológica" se utilizaron como herramientas de medición. En el estudio, se pidió a las personas que escribieran una palabra para expresar sus pensamientos sobre el proceso CoViD-19 para análisis descriptivos, y los datos recopilados se visualizaron con el programa de análisis de datos cualitativos "MAXQDA". Además, los datos se presentan en gráficos en el análisis de otras variables. En el análisis estadístico del estudio se utilizó estadística descriptiva, se utilizó la prueba t para determinar la diferencia entre grupos independientes, se utilizó el análisis de correlación de Pearson para determinar las relaciones entre las variables y se utilizó el análisis de regresión lineal simple para determinar la fuerza de la variable independiente en la predicción de la variable dependiente. Como resultado, se observaron estados emocionales

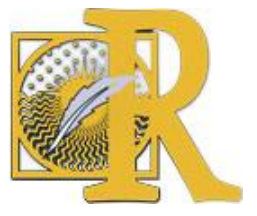

Fecha de recepción: 23-01-2021 Fecha de aceptación: 29-04-2020 
predominantemente negativos en los individuos durante el período de cuarentena. Sin embargo, a medida que aumenta la participación en la actividad física, aumentará el nivel de resiliencia psicológica y disminuirá la percepción de aburrimiento en el tiempo libre. Además, se encontró que la percepción de aburrimiento en el tiempo libre fue un determinante importante del nivel de resiliencia psicológica, y que explica alrededor del $15 \%$ de la varianza.

\section{PALABRAS CLAVE.}

COVID-19, aburrimiento en el ocio, resiliencia psicológica, actividad física, estado emocional

\section{ABSTRACT.}

This research was conducted in the quarantine process implemented in the CoViD-19 outbreak to examine the relationship between the perception of the boredom of individuals in leisure times and psychological resilience levels, and to describe the leisure activities of individuals, participation in physical activity and emotional state. Accordingly, a total of 2214 voluntary individuals living in Turkey participated with 909 men (41.1\%) (X̄age=33.83 \pm 10.73 ),

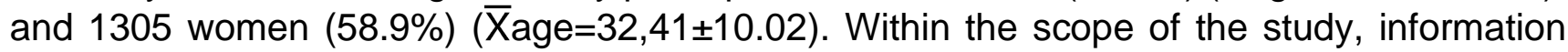
about demographic variables, physical activity and emotional state were collected with the form created by the researchers. In the study, "Leisure Boredom Scale" and "Psychological Resilience Scale" were used as the measurement tools. In the study, individuals were asked to write a word expressing their thoughts on the CoViD-19 process for descriptive analyses, and the collected data were visualized with the "MAXQDA" qualitative data analysis program. In addition, the data are presented in charts in the analysis of other variables. In the statistical analysis of the study, descriptive statistics were used, t-test was used to determine the difference between independent groups, Pearson correlation analysis was used to determine the relationships between variables, and simple linear regression analysis was used to determine the strength of the independent variable in predicting the dependent variable. As a result, predominantly negative emotional states were observed in individuals during the quarantine period. However, as the participation in physical activity increases, the level of psychological resilience will increase and the perception of boredom in leisure time will decrease. Besides, it was found that the perception of boredom in leisure time was an important determinant of the level of psychological resilience, and that it explains about $15 \%$ of the variance.

\section{KEY WORDS.}

CoViD-19, leisure boredom, psychological resilience, physical activity, emotional state.

\section{Introduction.}

The new coronavirus disease, first appeared in Wuhan, China in December and named as 2019-nCoV, has become an epidemic that soon affected the world (Jalali, Shahabi, Bagheri Lankarani, Kamali, \& Mojgani, 2020; Lu, Stratton, \& Tang, 2020). On January 30, 2020, the World Health Organization (WHO) announced that this outbreak in China had been declared as "Public Health Emergency of International Concern (PHEIC)" (Sohrabi et al., 2020). It was declared as "Pandemic" by the World Health Organization on March 11, 2020 as a result of

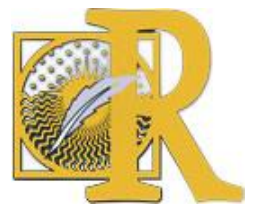

Fecha de recepción: 23-01-2021 Fecha de aceptación: 29-04-2020 
the threat of public health globally by crossing the borders of Asia (World Health Organization, 2020c). As of May 2020, it infected more than 5 million people in 216 countries worldwide, killing more than 350,000 people (World Health Organization, 2020a).

Strict measures taken in China where the outbreak emerged have slowed the incidence of new cases (Anderson, Heesterbeek, Klinkenberg, \& Hollingsworth, 2020; Kucharski et al., 2020). However, the CoViD-19 outbreak has affected many countries including particularly the United States of America, Russia, Italy, the United Kingdom, Spain, Germany, and Turkey. A total of more than 150,000 people have been reported to have been infected and about 5,000 have died since 11 March 2020, when the first case was seen in Turkey. For this reason, many countries have declared quarantine to socially distance their citizens who are infected or likely to be, and to isolate themselves at home in order to reduce the infection rate and prevent overloading health systems (Brooks et al., 2020; Rodríguez, Crespo, \& Olmedillas, 2020). With the increase in the impact of the virus worldwide, quarantine measures have been increased in many countries (World Health Organization, 2020b). Turkey is one of the countries that implemented quarantine measures. However, there is no long-term quarantine process in Turkey compared to other countries. Restrictions have been imposed to cover weekends in 31 cities with large populations. However, individuals under the age of 20 and over 65 are completely restricted from going out.

Because it is associated with quarantine applications interrupting the work routine, which affect social life intensely, it may cause perception of boredom in people (Muscogiuri, Barrea, Savastano, \& Colao, 2020). The perception of boredom is most commonly caused by lack of activity or the presence of an unwanted activity (Fahlman, Mercer-Lynn, Flora, \& Eastwood, 2013). In this context, the perception of boredom is defined in various ways by researchers as a disturbing psychophysiological condition created by monotonous lifestyle in individuals (O'Hanlon, 1981; Smith, 1981; Harris, 2000) and a state of low stimulation and dissatisfaction attributed to an environment that is not stimulating enough (Mikulas \& Vodanovich, 1993). Although researchers have not yet been able to agree on a common definition of boredom (Vodanovich, 2003), many see the perception of boredom as a secondary symptom of other psychological conditions (Goldberg, Eastwood, Laguardia, \& Danckert, 2011). Studies show that the perception of boredom is significantly related to negative emotional states such as depression (Watt \& Davis, 1991), anxiety (LePera, 2011), loneliness (Skues, Williams, Oldmeadow \& Wise, 2016) and anger (Dahlen, Martin, Ragan, \& Kuhlman, 2004; Rupp \& Vodanovic, 1997). During the quarantine period in which the boredom perception is heavily felt, negative moods such as stress (DiGiovanni, Conley, Chiu, \& Zaborski, 2004), anxiety (Halder, Mahato, \& Manot, 2020), depression (Hawryluck et al., 2004), low mood (Lee, Chan, Chau, Kwok, \& Kleinman, 2005), emotional exhaustion (Maunder et al., 2003), and perception of boredom (Brooks et al., 2020) emerge in individuals.

It can be said that the unusual and disproportionately increasing leisure time during the quarantine period has led to a major change in everyday life. While leisure time refers to a time frame that individuals can freely use without restrictions or coercion (Godbey, 1994; Torkildsen, 2005), people's leisure experience is changing in accordance with the effects of quarantine practices. The perception of boredom in leisure, which is an important study topic in leisure literature, is described as "the subjective perception available that leisure

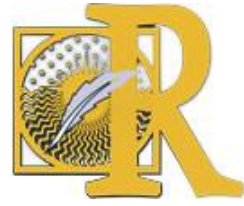

Fecha de recepción: 23-01-2021 Fecha de aceptación: 29-04-2020

Dursun, M, Emre, Y, Arı, C., Ulun, C \& Kocamaz, S. Covid-19 en Turquía: aburrimiento en el ocio, resiliencia psicológica, actividad física y estado emocional

International Journal of Educational Research and Innovation (IJERI), 15, 460-486 ISSN: 2386-4303 DOI https://doi.org/10.46661/ijeri.5588 
experiences are not sufficient to instrumentally satisfy needs for optimal arousal" (Iso-Ahola \& Weissinger, 1990). In studies focusing on leisure and boredom perception, it is shown that the two concepts are closely related (Iso-Ahola \& Weissinger, 1987; Oh, Caldwell, \& Oh, 2001) and the cause of boredom in leisure times stem from two contradictory perceptions (Iso-Ahola \& Weissinger, 1990; Vodanovich \& Watt, 1999): (a) individuals have too much leisure time, (b) there is very little activity to be done in leisure time. Therefore, it can be said that individuals have too much leisure time in the quarantine process and that there's limited activity to do which can lead to the perception of boredom in leisure time.

Departing from the fact that individuals participating in activities with increased leisure time due to the quarantine process are psychologically healthier (Pearson, 1998; Sato, Jordan, \& Funk, 2014), the concept of psychological resilience discussed in the scope of research is defined as a personality trait that emerges as a source of resilience when faced with stressful events in daily life (Kobasa, 1979), as adaptation to life in the face of physical and psychological challenges (Holahan \& Moos, 1985), and the ability of an individual to adapt and cope with adverse situations (Block \& Kremen, 1996). The concept of psychological resilience refers to a personality trait consisting of three dimensions that are "commitment" as the individual tends to deal with various areas of life (Kobasa, 1979; Kobasa, Maddi, \& Kahn, 1982), "control" as a belief of being able to affect the outcomes of events rather than being helpless when faced with difficulties in life (Kobasa, 1979; Sinclair \& Tetrick, 2000) and "challenge" as a belief of change being a stimulus for development rather than a component threatening safety (Kobasa et al., 1982; Lambert \& Lambert, 1999; Maddi et al., 2006). Psychological resilience personality trait affects being able to be resistant to stressful situations in daily life and well-being with the implementation of effective coping strategies (Işık, 2016). In this context, it is thought that the stress factor affecting the daily lives of people increases with the quarantine process and one of the ways to deal with it is to participate in regular physical activity (Hammami, Harrabi, Mohr, \& Krustrup, 2020; Lippi, Henry, \& SanchisGomar, 2020). It is emphasized by researchers that physical activity has positive effects on physical and mental health and is an effective tool for preventing diseases, strengthening the immune system and reducing stress levels (Frühauf, Schnitzer, Schobersberger, Weiss, \& Kopp, 2020). Accordingly, it is predicted that regular physical activity performed in leisure time during the quarantine process will drive individuals away from sedentary life and that negative emotional states experienced in this process can be prevented.

Departing from the relationship between both leisure time behaviors and psychological resilience, and the physical activity and emotional state (Hull, 1990; Hills \& Argyle, 1998; Giacobbi, Hausenblas, \& Frye, 2005; Iwasaki, Mackay, Mactavish, Ristock, \& Bartlett, 2006; Chekroud et al., 2018; Mandolesi et al., 2018; Kekäläinen, Freund, Sipilä, \& Kokko, 2019; Rodrigues, Teixeira, Cid, \& Monteiro, 2019; Matias, Dominski, \& Marks, 2020), within the scope of this study, it was aimed to determine the relationship between perception of boredom in leisure time and psychological resilience in individuals affected by the quarantine process implemented in Turkey during CoViD-19 outbreak, and to describe their status of how they use their leisure time, their participation in physical activity, and their moods.

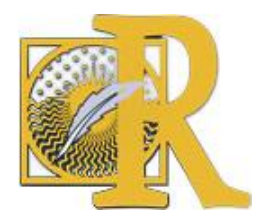

Fecha de recepción: 23-01-2021 Fecha de aceptación: 29-04-2020 Dursun, M, Emre, Y, ArI, C., Ulun, C \& Kocamaz, S. Covid-19 en Turquía: aburrimiento en el ocio, resiliencia psicológica, actividad física y estado emocional 


\section{Method.}

\section{Research Model.}

This study aiming to determine the relationship between the perception of boredom in leisure time and psychological resilience in individuals affected by the quarantine process implemented in Turkey during the CoViD-19 pandemic was designed by using a relational screening model. Relational research aims to identify the relationships between two or more variables and the coexistence of change or the level of change with these variables (Fraenkel, Wallen, \& Hyun, 2012; Creswell \& Creswell, 2017).

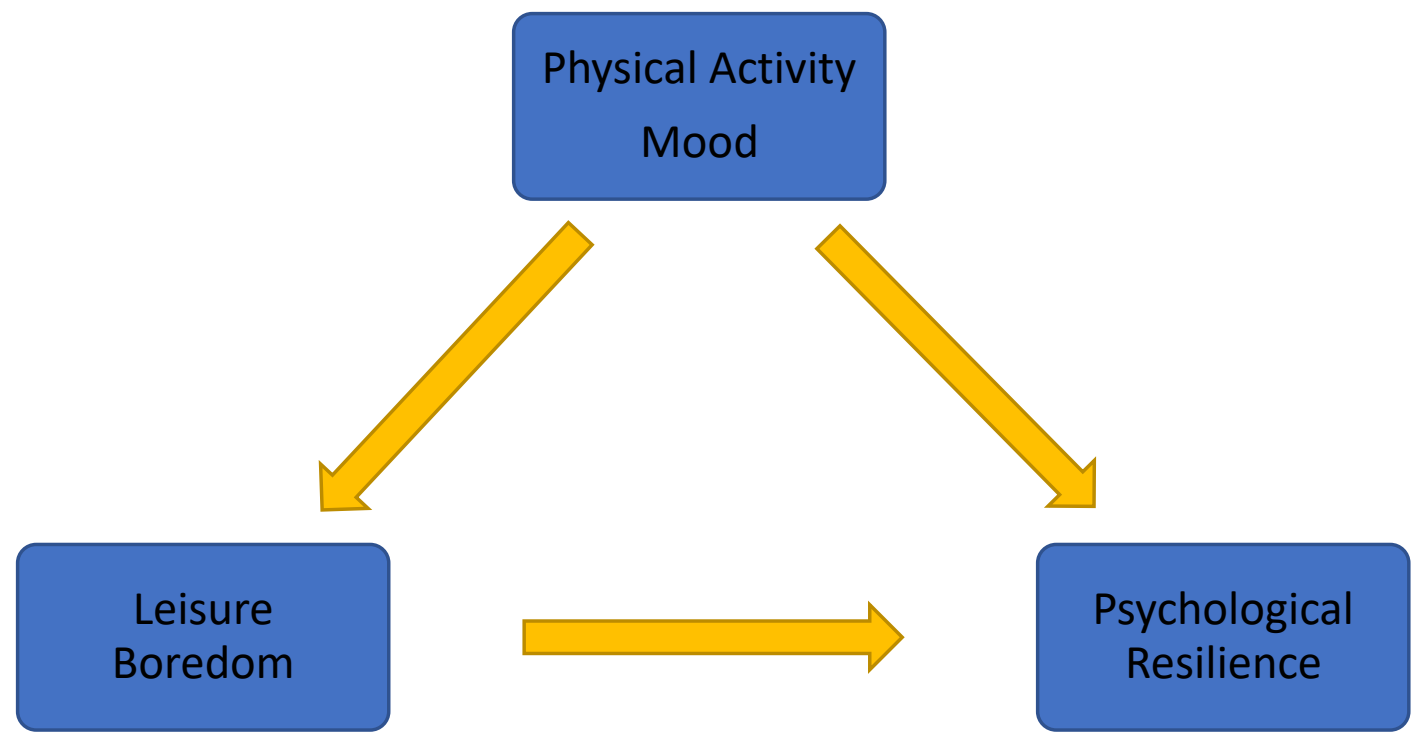

Figure 1. Research model

\section{Study Group.}

Since the environment created by the CoViD-19 outbreak does not provide the opportunity to collect data face-to-face, the participants were selected using appropriate sampling methods by taking into account the easy access and affordability of our study (Gravetter \& Forzano, 2012). Accordingly, measurement tools were transferred to electronic media (Google Form) and data collection was carried out online between April 30 and May 9, 2020. Accordingly, with 909 men (41.1\%), ( $\left.\bar{X}_{\text {age33.83 }} \pm 10.73\right)$, and 1305 women $(58.9 \%),\left(\bar{X}_{\text {age }} 32.41 \pm 10.02\right)$, a total of 2.214 individuals participated in the study voluntarily. The descriptive statistical information about the participants of the study is given in Table 1. 
Table 1. Descriptive statistical information of the individuals participating in the study

\begin{tabular}{lccc}
\hline Variable & & $\mathbf{n}$ & $\%$ \\
\hline Gender & Man & 909 & 41.1 \\
& Woman & 1305 & 58.9 \\
\hline Level of Education & Primary school & 29 & 1.3 \\
& Middle school & 62 & 2.8 \\
& High school & 309 & 14.0 \\
& Associate degree & 225 & 10.2 \\
& Undergraduate & 1143 & 51.6 \\
& Graduate & 446 & 20.1 \\
\hline Marital Status & Married & 1078 & 48.7 \\
& Single & 1136 & 51.3 \\
\hline Total & & $\mathbf{2 2 1 4}$ & $\mathbf{1 0 0}$ \\
\hline
\end{tabular}

\section{Data Collection Tools.}

Personal Information Form: The personal information form consists of questions about participants' gender, age, education level, marital status and the number of physical activities engaged in weekly.

Leisure Boredom Scale (LBS): The scale was developed by Iso-Ahola and Weissinger (1990) to measure "individual differences in perceptions of boredom in leisure." The original scale consists of 16 items and one dimension. The adaptation of PBLS to Turkish was performed by Kara, Gürbüz, and Öncü (2014) and it consists of 10 questions and two dimensions that are: 'boredom' (5 items) and 'satisfaction' (5 items). PBLS is a 5-point Likert scale with 1 being "strongly disagree" and 5 "strongly agree". Kara et al. (2014) found the Cronbach Alpha internal consistency coefficient for the boredom sub-dimension as .72 and .77 for the satisfaction sub-dimension in the Turkish adaptation. The reliability coefficient of the scale in this study was .84 .

Psychological Resilience Scale (PRS): The "Psychological Resilience Scale" developed by Işık (2016) consists of 3 sub-dimensions and 21 items, namely "commitment" (7 items), "control" (7 items) and "challenge" (7 items). PRS is a 5-point Likert scale with 1 being "strongly disagree" and 5 "strongly agree". In developing the scale, Işık (2016) found the Cronbach Alpha internal consistency coefficient as .62 for the "commitment" dimension, .69 for the "control" dimension, and .76 for the "challenge" dimension. The high scores obtained from the sub-dimensions and the 
scale indicate that the level of psychological resilience is high (Işık, 2016). The reliability coefficient of the scale in this study was .84 .

\section{Descriptive Question Items.}

Within the scope of the research, the following questions were asked to individuals living in Turkey during CoViD-19 to describe the process, and the results were reported.

(1) Select the most appropriate option that defines your feelings (mood) in the CoViD-19 process (Figure 2).

This question was created to describe the emotional states that may occur in individuals during the quarantine process. In this context, participants were asked to select the option expressing the mood they experienced in the process. Plutchik (1980)'s wheel of emotions taken into consideration when selecting the emotional states.

\section{EMOTIONAL STATES}

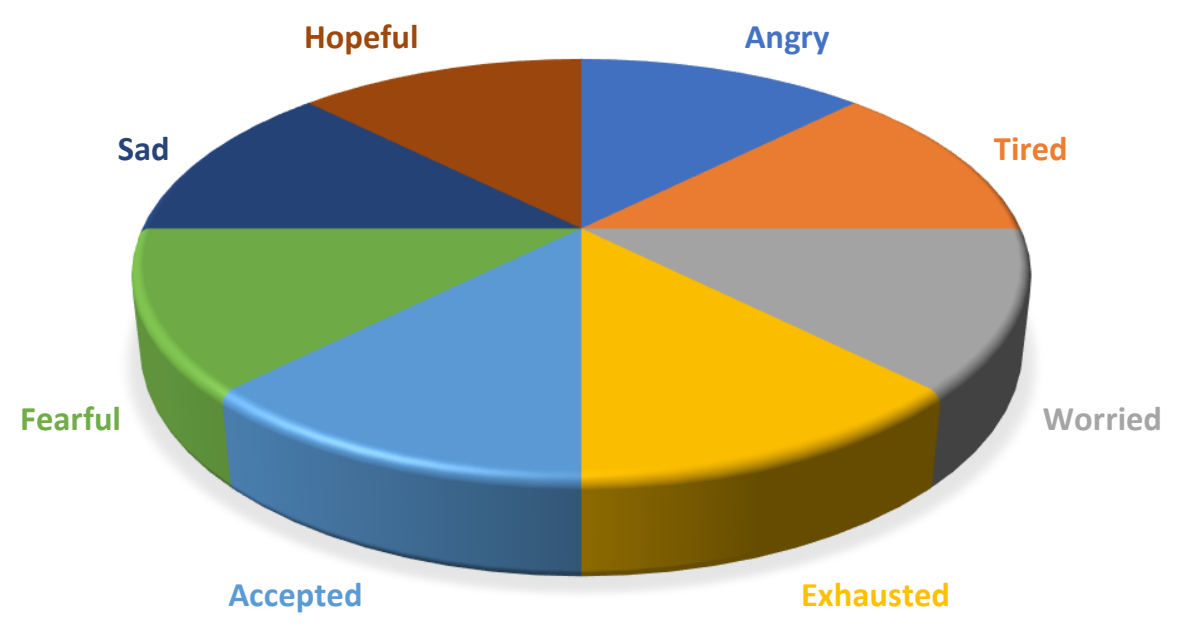

Figure 2. Moods evaluated within the scope of the study

(2) Can you describe the CoViD-19 process in 1 word?

Departing from the saying "a picture is worth a thousand words" by DePaulo and Wilkinson (2014), individuals were asked to write a word expressing their thoughts on the process. The data collected from this question were visualized by word cloud analysis. In the study, MAXQDA qualitative data analysis program was used for word cloud analysis. Word clouds are a method that allows visualization of words in text by taking into account their frequency (Hunt, Gao \& Xue, 2014) and allow researchers to visually present themes emerging from the data (Williams, Parkes and Davies, 2013). The purpose of visualizing data with a word cloud is not to make it aesthetically beautiful, but to make it clear (Fronza et al., 2013).

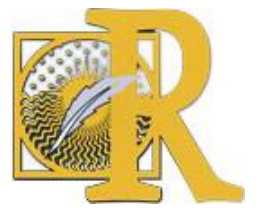

Fecha de recepción: 23-01-2021 Fecha de aceptación: 29-04-2020 
(3) Questions prepared to determine weekly levels of physical activity before and during the CoViD-19 period were prepared using the International Physical Activity Questionnaire (IPAQ).

\section{Data Analysis.}

SPSS 22.0 and AMOS 22.0 software were used for the statistical analysis of data obtained from the scales. In the study, first, the evaluation of blank data was performed for the appropriateness of the analysis and the control of the assumptions. As a result of this process, the data of 29 people who responded to the survey incorrectly and incompletely were excluded from the analysis. After this stage, considering the Mahalanobis distance, extreme value analyses were evaluated. As a result of extreme value analysis, the data of 21 people were excluded from the analysis and the data of the remaining 2214 people were analyzed.

It is stated in the literature that (Downey \& King, 1998; Carpita \& Manisera, 2011) there are techniques such as assigning a value or exclusion from the analysis. In this context, considering the number of the study group and the lack of answers to the scale items in 50 surveys, the data were excluded.

After this step, first the skewness-kurtosis values were examined for the normality test and the distribution was found to be normal (Tabachnick \& Fidell, 2013). Accordingly, T-Test was used for the differences between people's perceptions of positive and negative emotions in leisure time and their psychological resilience levels. For the T-Test, the values related to the level of exposure to the difference between the mean of the significant difference obtained as a result of Cohen's $d$ analysis were calculated. These values are accepted as "small" if they are .20, "medium" if they are .50 and "large" if .80 (Cohen, 1988).

In addition, the Pearson Moments Product Correlation analysis was used to determine the relationships between the variables within the scope of this study, and Simple Linear Regression analysis was used to determine the predictive power of the independent variable (perception of boredom at leisure) for the dependent variable (psychological resilience). After determining that the correlation values among the variables included in the model, that are regression assumption criteria, were below 0.70 , the variance increase factor (VIF) was determined to be below 10, and the tolerance value was determined to be above 0.2, it was determined that there was no multicollinearity problem. (Farrar \& Glauber, 1967; Tabachnick \& Fidell, 2013).

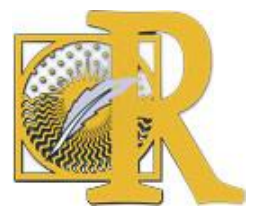

Fecha de recepción: 23-01-2021 Fecha de aceptación: 29-04-2020 


\section{Results}

\section{Results on Descriptive Statements.}

Physical Activity.

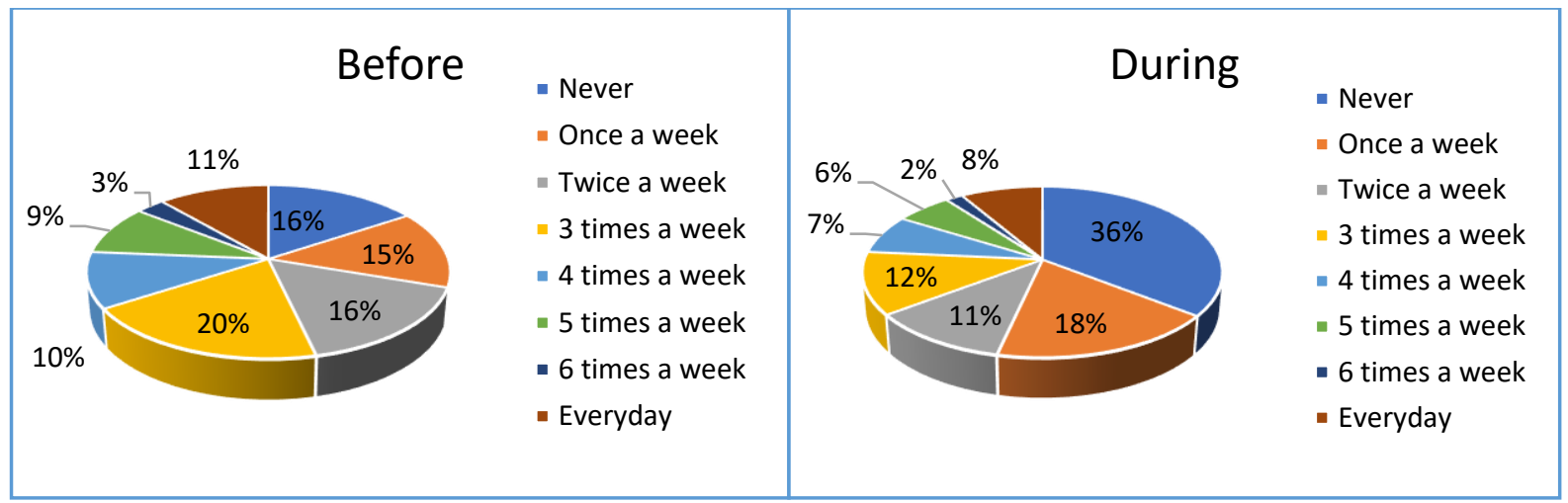

Figure 3. Levels of engaging with physical activities before and during the quarantine process

Figure 3 shows the participants' level of engagement with weekly physical activities before and during CoViD-19 quarantine practices. According to the figure, $20 \%$ of the participants engaged in physical activities 3 times a week, 16\% never, $16 \%$ engaged twice a week, $15 \%$ once a week, $11 \%$ everyday, $10 \% 4$ times a week, $9 \% 5$ times a week, and $3 \%$ engaged in physical activities 6 times a week before the quarantine process. During the quarantine, 36\% of the participants never engaged in physical activities, $18 \%$ once a week, $12 \% 3$ times a week, $11 \%$ twice a week, $8 \%$ everyday, $7 \% 4$ times a week, $6 \% 5$ times a week, and $2 \% 6$ times a week. According to Figure 1, a general decrease in weekly physical activity participation levels was observed during quarantine. When this change is examined, it is observed that $84 \%$ of individuals participated in physical activity at least once a week before quarantine, while this rate decreased to $64 \%$ during quarantine. It is believed that this $20 \%$ decrease in the level of participation in physical activity during the CoViD-19 process occurred due to the effects of quarantine and social isolation practices in the society. This finding obtained in this context can be interpreted as individuals tend towards a more sedentary lifestyle with the restriction of their movement areas.

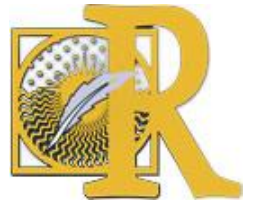

Fecha de recepción: 23-01-2021 Fecha de aceptación: 29-04-2020 


\section{Emotional States.}

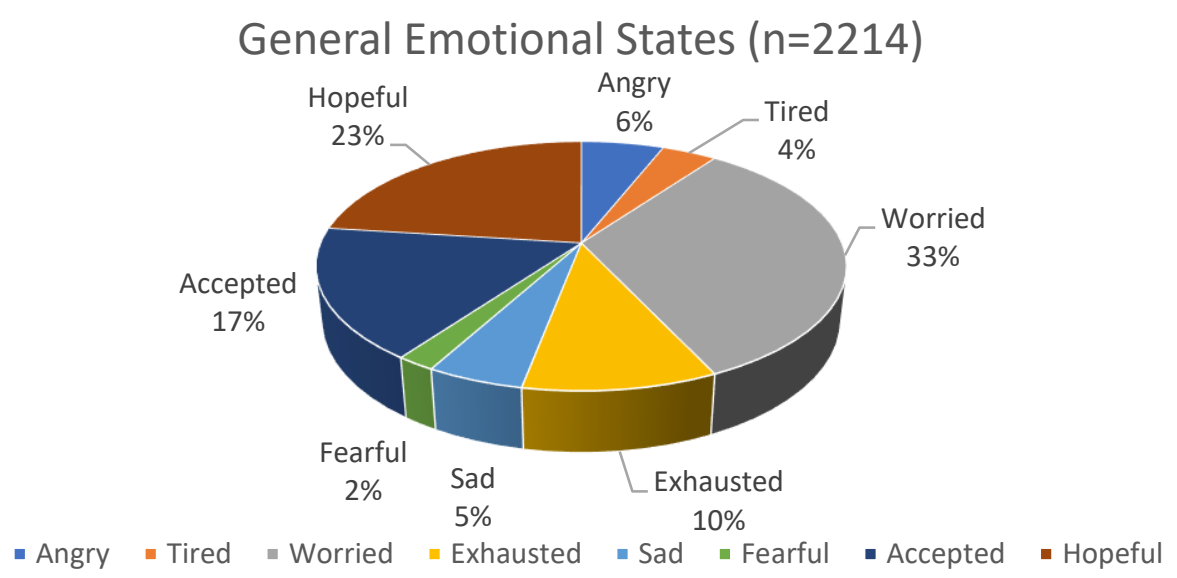

Figure 4. General moods of individuals during quarantine applications

When Figure 4 is examined, participants of the study evaluated the moods they experienced during the CoViD-19 quarantine applications. During the quarantine process, $33 \%$ of individuals were worried, $23 \%$ were hopeful, $17 \%$ accepting, 10\% exhausted, $6 \%$ angry, $5 \%$ were sad, $4 \%$ were tired and $2 \%$ were fearful. When moods were examined by gender, it was observed that women participants responded with more intense emotional responses than men (Figure 5).

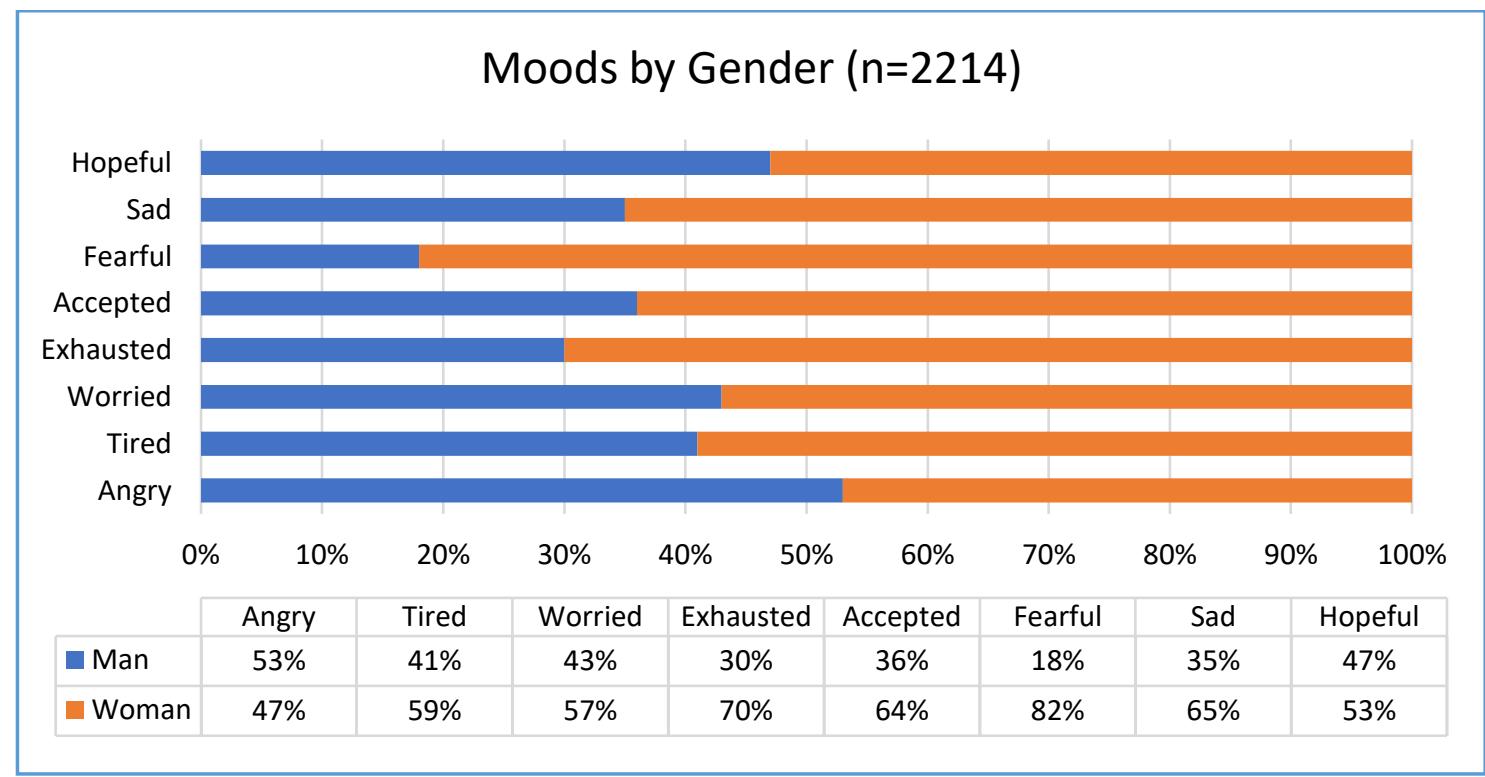

Figure 5. Individuals moods by gender during quarantine

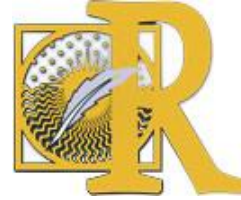

Fecha de recepción: 23-01-2021 Fecha de aceptación: 29-04-2020 
Word Cloud: Can You Describe the Covid-19 Process In 1 Word?

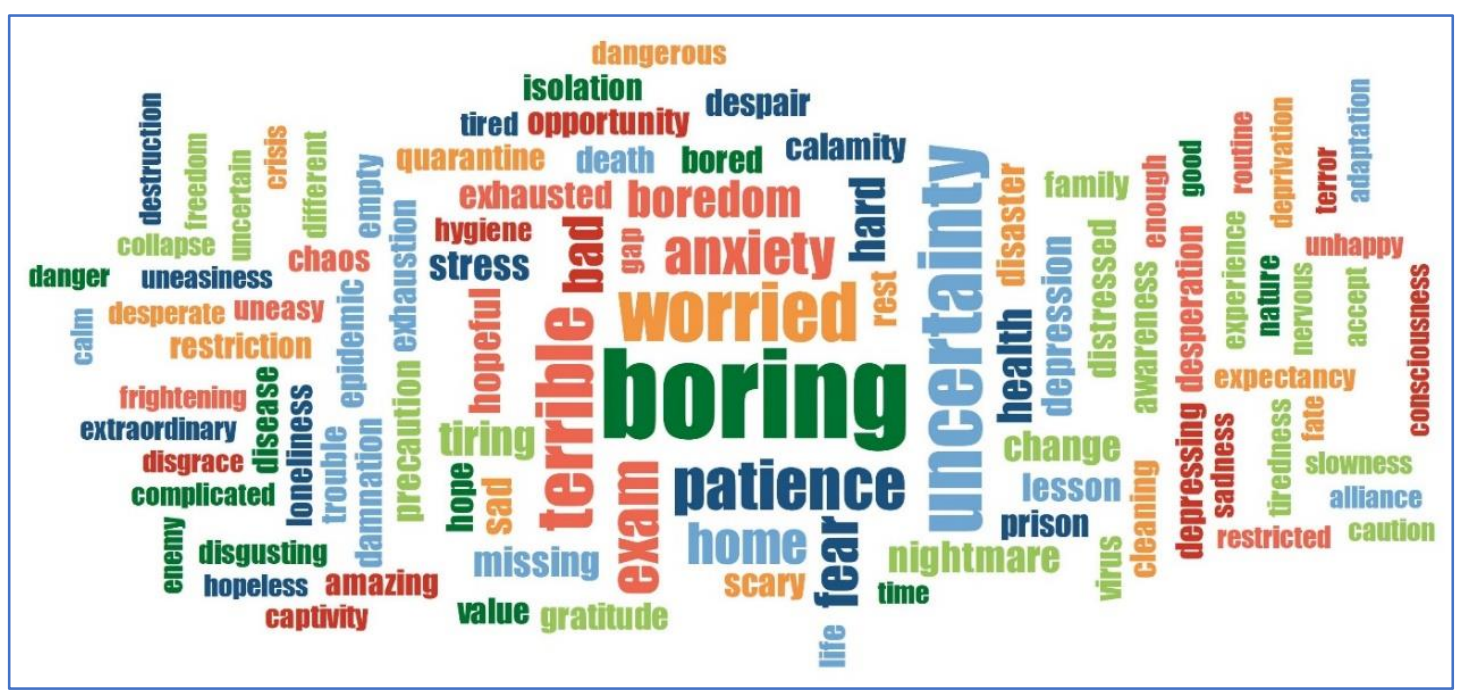

Figure 6. Word cloud of individuals' expressions about the CoViD-19 process

In the visualization by word cloud analysis shown in Figure 6 , it is seen that words such as boring, uncertainty, worried, terrible, patience, exam, anxiety, fear, and home are prominent. In this context, it is thought that the words that the CoViD-19 quarantine process evokes in individuals overlap with the research topic.

Leisure Time.

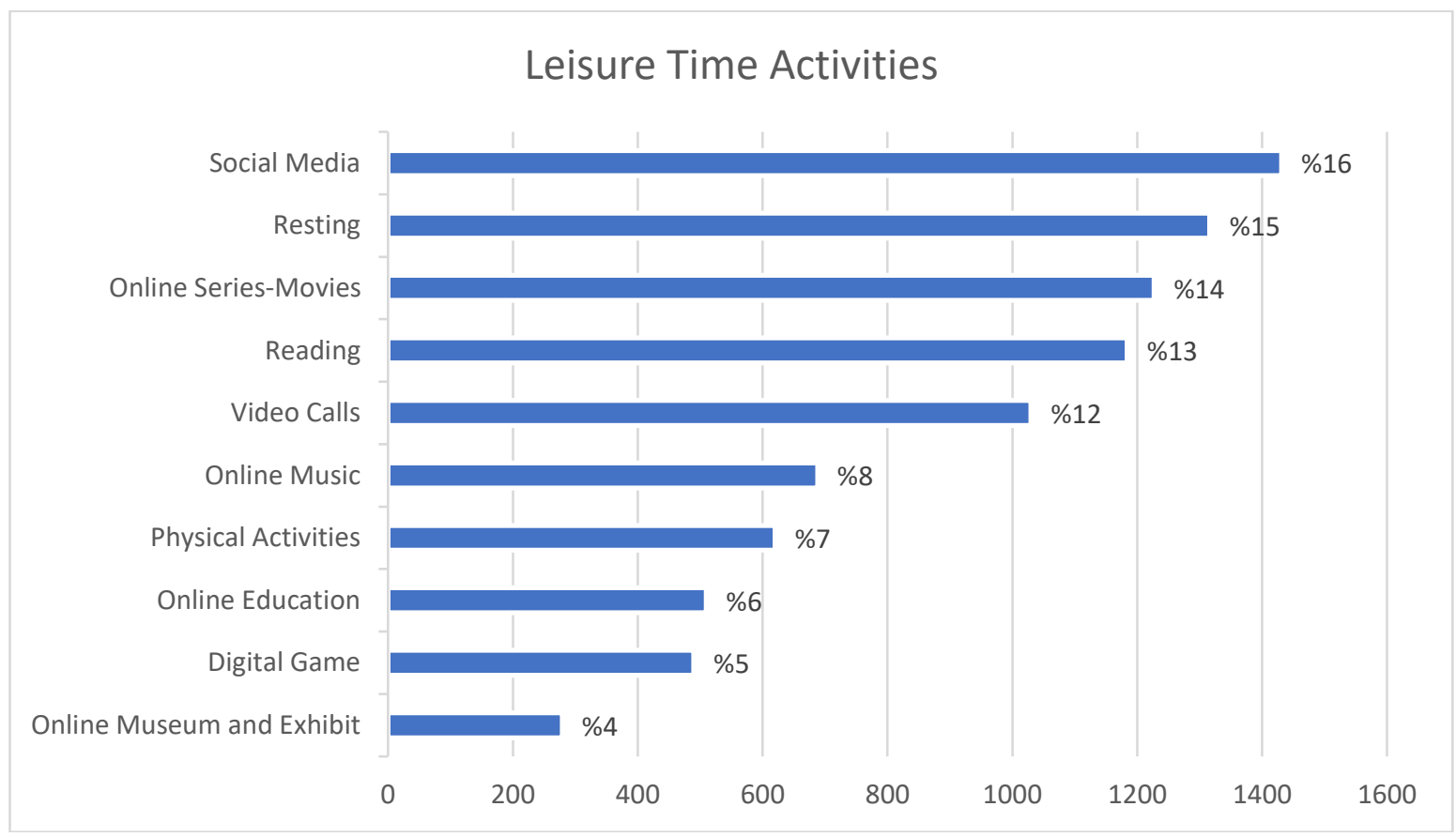

Figure 7. Leisure activities at home during CoViD-19 process

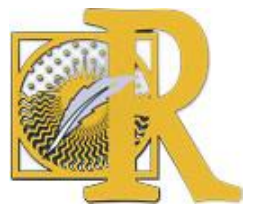

Fecha de recepción: 23-01-2021 Fecha de aceptación: 29-04-2020 
In Figure 7, participants of the study evaluated the leisure activities they engaged with during CoViD-19 quarantine process. According to the figure, $16 \%$ of the participants engaged with social media, $15 \%$ with resting, $14 \%$ with online shows-movies, $13 \%$ with reading, $12 \%$ with video calls, $8 \%$ with online music, $7 \%$ with physical activities, $6 \%$ with online education, $5 \%$ with digital games, and $4 \%$ with online museum and exhibits during the quarantine applications. In addition, most of the participants involved in the study stated that they observed a change in leisure habits due to the quarantine process (Figure 8).

Have your leisure habits changed?

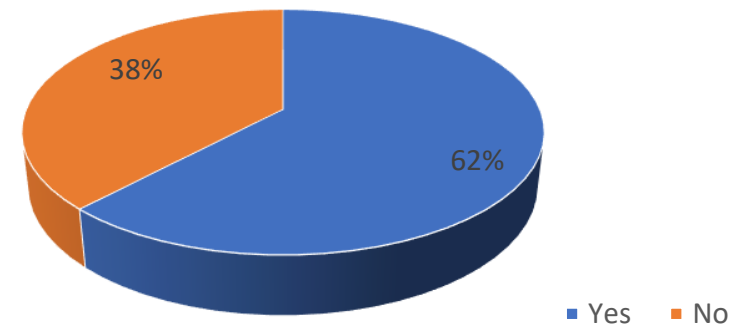

Figure 8. Change in participants' leisure habits during CoViD-19 process

\section{Results on The Scales Used in The Study}

Table 2. Descriptive statistical values for variables included in the study

\begin{tabular}{lcccccc}
\hline \multicolumn{1}{c}{ Scales } & Dimensions & $\mathbf{n}$ & $\overline{\mathbf{X}}$ & SD & Skewness & Kurtosis \\
\hline Leisure & Boredom & 2214 & 12.110 & 4.259 & .345 & -.619 \\
Boredom & Satisfaction & 2214 & 12.377 & 3.452 & .268 & .018 \\
& LB-Total & 2214 & 24.487 & 6.810 & .147 & -.440 \\
\hline Psychological & Challenge & 2214 & 21.538 & 3.552 & -.426 & 1.013 \\
Resilience & Commitment & 2214 & 19.417 & 3.615 & -.239 & .378 \\
& Control & 2214 & 18.187 & 3.070 & -.108 & .328 \\
& PR-Total & 2214 & 59.143 & 8.635 & -.265 & .995 \\
\hline
\end{tabular}

It is determined in Table 2 that skewness and kurtosis values were between $(-1.5,+1.5)$ and the data showed normal distribution (Tabachnick \& Fidell 2013). 
Table 3. Goodness of fit index values for scales according to CFA results

\begin{tabular}{lccccc}
\hline Scales & p & RMSEA & SRMR & RMR & GFI \\
\hline Leisure Boredom & .00 & .091 & .055 & .062 & .94 \\
Psychological Resilience & .00 & .068 & .053 & .041 & .91 \\
\hline
\end{tabular}

In Table 3, when the goodness of fit index values was examined for the Perceptions of Boredom in Leisure, the RMSEA values was determined to be .091. It is stated in the literature that the value ranges between .08 and .10 show a moderate level of goodness of fit (Steiger, 2000; Kline, 2015). The SRMR value was .055 and RMR was .062. Kline (2015) states that these values below 0.10 indicate that the model's goodness of fit is good. The GFI was found to be .94. It was seen that a value of .90 and above indicates a good level of fitness (Thompson, 2004; Kline, 2015).

When the goodness of fit index values of Psychological Resilience was evaluated, the RMSEA values was determined to be .068 . Hu and Bentler (1999) state that values below .08 are acceptable. SRMR value was .053 and the RMR was .041. Kline (2015) states that these values below .10 indicate that the model's goodness of fit is good. The GFI was .91. In the literature, a value of .90 and above has been found to be a good fit (Thompson, 2004; Kline, 2015). The results obtained show that both scales had a good level of fitness within the scope of research.

Chi-square statistics are affected by the sample volume and increase as sample volume increases (Muthen, 2001). It is difficult to obtain insignificant chi-square when the sample volume is 200 or more. As in the sample volume, the size of the model causes an increase in chi-square value (Kline, 2011). Accordingly, considering the sample group of the study $(n=2214)$, the $x^{2 / d f}$ fit index value was not evaluated within the scope of the study.

Table 4. T-test results on perceptions of boredom in leisure by gender

\begin{tabular}{lccccccccc}
\hline Scale & Gender & $\mathbf{n}$ & $\overline{\mathbf{X}}$ & SD & $\mathbf{f}$ & $\mathbf{t}$ & $\mathbf{d f}$ & $\mathbf{p}$ & Cohen's d \\
\hline LB & Man & 909 & 25.254 & 6.963 & 3.769 & 4.440 & 2212 & .000 & .19 \\
& Woman & 1305 & 23.953 & 6.652 & & & & & \\
\hline
\end{tabular}

When the values of perception of boredom in leisure time according to the gender variable of the individuals participating in the study were examined in Table 4, it was found that there was a statistically significant difference $\left(t_{(2212)}=4,440, p<.05\right)$. Accordingly, it was determined that the means of perceptions of boredom of men $(\bar{X}=25,254)$ were higher than that of women $(\bar{X}=$ $23,953)$. It can be said that the Cohen's $d$ value, calculated from the difference between the means, is close to the small effect.

Table 5. T-Test results on psychological resilience levels of participants by gender variable

\begin{tabular}{|c|c|c|c|c|c|c|c|c|c|}
\hline Scale & Gender & $\mathbf{n}$ & $\overline{\bar{X}}$ & SD & $f$ & $t$ & df & p & Cohen's d \\
\hline PR & $\begin{array}{c}\text { Man } \\
\text { Woman }\end{array}$ & $\begin{array}{c}909 \\
1305\end{array}$ & $\begin{array}{l}59.371 \\
58.983\end{array}$ & $\begin{array}{l}9.442 \\
8.025\end{array}$ & 15.168 & 1.040 & 2212 & .299 & \\
\hline
\end{tabular}

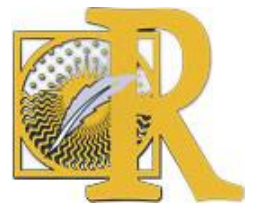

Fecha de recepción: 23-01-2021 Fecha de aceptación: 29-04-2020 
When the psychological resilience levels of the individuals participating in the study were examined by gender in Table 5 , there was no statistically significant difference $\left(t_{(2212)}=1,040\right.$, $p<.05)$. However, when the average scores were examined, it is seen that the psychological resilience levels of men $(\bar{X}=59.371)$ are higher than that of women $(\bar{X}=58.983)$.

Table 6. T-Test results on perceptions of boredom in leisure by positive and negative moods

\begin{tabular}{lccccccccc}
\hline Scale & Mood & $\mathbf{n}$ & $\overline{\mathbf{X}}$ & SD & $\mathbf{f}$ & $\mathbf{t}$ & $\mathbf{d f}$ & $\mathbf{p}$ & Cohen's d \\
\hline LB & Negative Mood & 1407 & 25.965 & 6.686 & 9.262 & 14.069 & 2212 & .000 & .62 \\
& Positive Mood & 807 & 21.910 & 6.236 & & & & & \\
\hline
\end{tabular}

When the participants' values of perception of boredom in leisure time were examined by the emotional state variable in Table 6 , it was found that there was a statistically significant difference $\left(t_{(2212)}=14,069, p<.05\right)$. Accordingly, it was determined that the individuals with negative emotions had a higher mean of boredom perception $(\bar{X}=25.965)$ than individuals with positive emotions ( $\bar{X}=21.910)$. It can be said that the Cohen's $d$ value, calculated from the difference between the averages, is close to the medium effect.

Table 7. T-Test results on psychological resilience levels by individuals' positive and negative moods

\begin{tabular}{lccccccccc}
\hline Scale & Mood & $\mathbf{n}$ & $\overline{\mathbf{X}}$ & SD & $\mathbf{f}$ & $\mathbf{t}$ & $\mathbf{d f}$ & $\mathbf{p}$ & Cohen's d \\
\hline PR & Negative Mood & 1407 & 58.068 & 8.617 & .000 & -7.833 & 2212 & .000 & .34 \\
& Positive Mood & 807 & 61.016 & 8.348 & & & & & \\
\hline
\end{tabular}

When the psychological resilience levels of the individuals participating in the study were examined by the mood variable in Table 7 , it was found that there was a statistically significant difference $\left(t_{(2212)}=-7.833, p<.05\right)$. Accordingly, it was determined that individuals with positive emotional state $(\bar{X}=61.016)$ had higher levels of psychological resilience than individuals with negative emotional state $(\bar{X}=58.068)$.

Table 8. Pearson correlation analysis results on the perception of boredom in leisure time by the number of physical activity engaged during CoViD-19

\begin{tabular}{lcc}
\hline Variable (n=2214) & & Leisure Boredom \\
\hline How often do you do physical & $\mathrm{r}$ & -.152 \\
\cline { 2 - 3 } activity during CoViD-19? & $\mathrm{p}$ & .000 \\
\cline { 2 - 3 } & $\overline{\mathrm{X}}$ & 24.487 \\
\cline { 2 - 3 } & $\mathrm{SD}$ & 6.810 \\
\hline
\end{tabular}


In Table 8, when individuals' perception of boredom according to the number of weekly physical activities was examined, it was found that there was a statistically significant relationship at a low level in the positive direction $(r=-.152 ; p<.05)$. These results can be interpreted as the perception of boredom decreases in leisure time as participation in physical activity increases.

Table 9. Pearson correlation analysis results of individuals' psychological resilience levels based on the number of physical activity they performed during CoViD-19

\begin{tabular}{lcc}
\hline Variable (n=2214) & & Psychological Resilience \\
\hline How often do you do physical & $\mathrm{r}$ & .147 \\
\cline { 2 - 3 } activity during CoViD-19? & $\mathrm{p}$ & .000 \\
\cline { 2 - 3 } & $\overline{\mathrm{X}}$ & 59.143 \\
\cline { 2 - 3 } & $\mathrm{SD}$ & 8.635 \\
\hline
\end{tabular}

When the psychological resilience levels of individuals according to the number of weekly physical activities were examined in Table 9, it was found that there was a statistically significant relationship at a low level $(r=.147 ; p<.05)$. These results can be interpreted as the level of psychological resilience of individuals will increase as participation in physical activity increases.

\section{Results of The Regression Analysis.}

In the analysis of the data, first, the Pearson Moments Product Correlation analysis was conducted in order to test the relationships between the predictive variable of "perception of boredom at leisure" and the predicted variable of "psychological resilience". The relationships between variables are presented in Table 10.

Table 10. Pearson correlation analysis results for the relationship between the perception of boredom in leisure and psychological resilience

\section{Variable $(n=2214)$ \\ Psychological Resilience}

\begin{tabular}{lcc}
\hline Leisure Boredom & $r$ & -.385 \\
\cline { 2 - 3 } & $p$ & .000 \\
\hline
\end{tabular}

In Table 10, when the individuals' perception of boredom at leisure time and psychological resilience levels were examined, it was found that there was a statistically significant relationship at a negative level $(r=-.385 ; p<.05)$. These results can be interpreted as individuals' level of psychological resilience increases as their perception of boredom with leisure decreases.

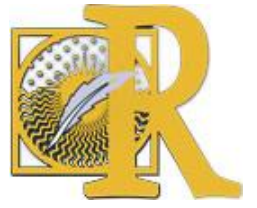

Fecha de recepción: 23-01-2021 Fecha de aceptación: 29-04-2020 
Table 11. Results of simple linear regression analysis related to prediction of the perception of boredom in leisure of psychological resilience levels

\begin{tabular}{|c|c|c|c|c|c|}
\hline $\begin{array}{l}\text { Predictive } \\
\text { Variable }\end{array}$ & B & Standart Error & Beta & $\mathbf{t}$ & $p$ \\
\hline Leisure Boredom & -.488 & .025 & -.385 & -19.597 & .000 \\
\hline $\mathrm{R}=.385 \quad \mathrm{R}^{2}=.148$ & Durbin V & son $=1.676$ & .038 & $\mathrm{P}<.000$ & \\
\hline
\end{tabular}

When the simple linear regression analysis results were examined in Table 11, it is seen that the perception of boredom in leisure time significantly predicts the psychological resilience levels of individuals and explains approximately $15 \%$ of the variance $\left(R=.385, R^{2}=.148\right)$. The standardized regression coefficient $(\beta)$ of the perception of boredom in leisure time was found to be -.385 .

\section{Discussion.}

This study was carried out to determine the relationship between the perception of boredom in leisure time and psychological resilience in individuals affected by the quarantine process implemented in Turkey during the CoViD-19 pandemic, and to describe the participation in physical activity, emotional states, and leisure activities of 2214 individuals who participated in the study.

\section{Findings on the Gender Variable.}

According to the results of the analysis, it was determined that men's perception of boredom in leisure time is higher than that of women. There are studies in the literature showing that men are more bored than women (Shaw, Caldwell, \& Kleiber, 1996; Newberry \& Duncan, 2001; Wegner, Flisher, Chikobvu, Lombard, \& King, 2008; Wegner \& Flisher, 2009). It is thought that this is due to men having more leisure time than women (Searle \& Jackson, 1985; Shaw, 1994; Lee \& Bhargava, 2004; Beck \& Arnold, 2009).

When the psychological resilience levels were examined, no significant difference was found. Research findings examining the effect of gender on psychological resilience differ in the literature. There are studies similar to our research findings (Harrison, Loiselle \& Semenic, 2002; Crowley, Hayslip \& Hobdy, 2003; Chan, 2003). On the other hand, a study conducted by Gatab \& Ghajari (2013) found that female students' psychological resilience levels were higher than that of male students. In a study in which the relationship between psychological resilience and mental health was found significant, it was revealed that women had more psychological resilience than men (Rudwan \& Alhashimia, 2018). These studies show differences with our findings.

\section{Findings on Mood.}

According to the results of the analysis, it was determined that the individuals who had negative emotions among the participants who were categorized in terms of their emotions were more bored in their leisure time compared to the individuals who had positive emotions. Therefore, the first hypothesis of the study was supported. Pfefferbaum and North (2020)

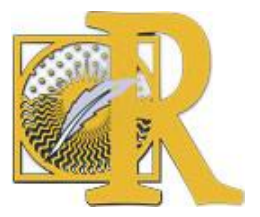

Fecha de recepción: 23-01-2021 Fecha de aceptación: 29-04-2020

Dursun, M, Emre, Y, Arı, C., Ulun, C \& Kocamaz, S. Covid-19 en Turquía: aburrimiento en el ocio, resiliencia psicológica, actividad física y estado emocional 
stated that quarantined people experience many negative emotions such as stress, depression, boredom, insomnia, fear, and frustration. This situation can be interpreted as a mood in which sudden and negative emotional states intensify in individuals experiencing the quarantine process (Zhang \& Ma, 2020). These feelings arise from the fact that individuals remain closed at home and do not efficiently utilize their significantly increased leisure time (Marafa \& Tung, 2004). Individuals with positive emotions are thought to effectively spend their leisure time in the quarantine process and maintain their emotional state. According to Iso-Ahola and Wessinger (1990), people's participation in leisure activities varies depending on their mood and creates positive feelings when they feel they have the appropriate leisure time for the activity. When several studies on this topic were examined: Iwasaki, Zuzanek, and Mannel (2001), in a study they conducted to address physical activity and health relationship, they stated that these created positive relationships and play an important role in avoiding negative emotional states. In another study conducted with a sample of university students, it was stated that there was a significant improvement in positive moods as a result of the exercises that students engaged in in their leisure time (Giacobbi et al., 2005). On the other hand, Schwartz and Campagna (2008) in a leisure study conducted with the elderly, examined the emotional changes experienced by the participants after ten weeks of exercise. As a result, it was reported that elderly people experienced both positive and negative emotional changes after the activity (Schwartz \& Campagna, 2008). Therefore, it can be said that our research findings are similar to the studies in the literature.

When the psychological resilience levels were examined, it was seen that individuals with positive mood had higher psychological resilience than individuals with negative mood. When studies on psychological resilience were examined, the findings of a study by Ong, Bergeman, Bisconti and Wallace (2006) found that participants who had positive emotional experiences exhibited a healing response to stress. In the same study, it was stated that psychological resilience creates significant findings in terms of participants' daily emotional states and stress levels. The results of another study showed that positive feelings of the participants play a critical role in their psychological resilience and physical well-being (Tugade, Fredrickson, \& Barret, 2004). In a study by Philippe, Lecours, and Beaulieu-Pelletier (2009), a positive relationship was found between positive emotions and psychological resilience. Min et al. (2013) found in their study that there was a negative relationship between the participants' psychological resilience levels and negative emotions (e.g. boredom). Therefore, it was observed that the findings obtained in our study also overlap with some examples in the literature.

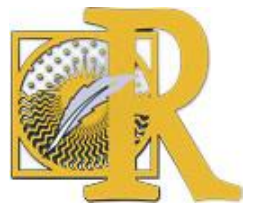

Fecha de recepción: 23-01-2021 Fecha de aceptación: 29-04-2020 


\section{Findings on the Physical Activity Variable.}

According to the results of the analysis, it can be stated that an increase in the participation in physical activity is inversely associated with the perception of leisure boredom, and thus the perception of boredom may decrease in participants who spend their leisure time with physical activities. Therefore, this situation can be considered as an important result in terms of exploring the nature of other variables that are thought to be related to physical activity. There are a limited number of studies in the literature that examine the relationship between the perception of leisure boredom and participation in regular physical activity. Kara (2019) stated that regular physical activity has positive effects on coping with the perception of boredom that occurs in leisure time. In a study conducted by Harasymchuk and Fehr (2010) on couples, it was reported that physical activity is an important tool in addition to activities such as reading, socializing, and watching television in dealing with people's perception of boredom. Accordingly, it is thought that the exercise practices that individuals who are exposed to quarantine and isolation practices will perform in their spare time will reduce their negative emotional states such as boredom in addition to positive effects on physical and mental health. When the psychological resilience levels were examined, it is seen that there is a positive relationship between the participants' physical activity and their psychological resilience. In other words, the increase that may occur in the frequency of physical activity of the participants will be in the same direction with the increase in psychological resilience feature. However, it has been stated that there is limited information about the interaction of these concepts in the literature as the studies in which physical activity is associated with psychological resilience are not very diverse (Hegberg \& Tone, 2015). However, there are several studies showing that physical activity increases positive moods of individuals (Janisse, Nedd, Escamilla, \& Nies, 2004; Penedo \& Dahn, 2005), reduces risk of depression (Schuch et al., 2018; Choi et al., 2019), and improves cognitive and mental health (Lau, Yang, Tsui, \& Kim, 2003; Spalding, Lyon, Steel, \& Hatfield, 2004; Gerber \& Pühse, 2009; Klaperski, von Dawans, Heinrichs, \& Fuchs, 2013). Therefore, it is thought that physical activity is an important parameter in terms of positive psychological components that have effects on individuals and departing from this point, it is thought to have an effect on psychological resilience.

Findings on the Relationship Between Leisure Boredom and Psychological Resilience. According to the results, it can be stated that if the perception of boredom in individuals is reduced, it will have an effect to cause a decrease in psychological resilience. Therefore, it can be stated that steps should be taken to distance individuals from the perception of boredom in leisure as a way of increasing psychological resilience. No studies focusing on the relationship between the boredom perception in leisure and psychological resilience were found in the literature.

In the light of the findings obtained within the scope of the research, the following recommendations can be made:

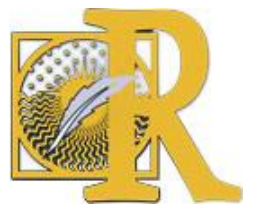

Fecha de recepción: 23-01-2021 Fecha de aceptación: 29-04-2020 Dursun, M, Emre, Y, Arı, C., Ulun, C \& Kocamaz, S. Covid-19 en Turquía: aburrimiento en el ocio, resiliencia psicológica, actividad física y estado emocional 


\section{Recommendations.}

(1) In order to protect our physical and mental health, it may be suggested to increase the level of in-home physical activity in order to prevent increased sedentary life in the CoViD19 process, based on the findings obtained within the scope of the research.

(2) Based on these findings, creating a daily routine during social isolation periods (physical activity, joining virtual environments, acquiring healthy living habits, following reliable resources, etc.) can help both adults and children maintain their physical and mental health.

(3) In order to maintain the level of societal health and welfare during possible crisis periods that may occur in the future, planning practices and policies regarding physical activity and leisure activities in accordance with the nature of this process can be recommended.

\section{References}

- Anderson, R. M., Heesterbeek, H., Klinkenberg, D., \& Hollingsworth, T. D. (2020). How will country-based mitigation measures influence the course of the COVID-19 epidemic? The Lancet, 395(10228), 931-934. https://doi.org/10.1016/S0140-6736(20)30567-5

- Beck, M. E., \& Arnold, J. E. (2009). Gendered time use at home: an ethnographic examination of leisure time in middle-class families. Leisure Studies, 28(2), 121-142. https://doi.org/10.1080/02614360902773888

- Block, J., \& Kremen, A. M. (1996). IQ and ego-resiliency: Conceptual and empirical connections and separateness. Journal of Personality and Social Psychology, 70(2), 349361. https://doi.apa.org/doi/10.1037/0022-3514.70.2.349

- Brooks, S. K., Webster, R. K., Smith, L. E., Woodland, L., Wessely, S., Greenberg, N., \& Rubin, G. J. (2020). The psychological impact of quarantine and how to reduce it: rapid review of the evidence. The Lancet, 395(10227), 912-920. https://doi.org/10.1016/S01406736(20)30460-8

- Carpita, M., \& Manisera, M. (2011). On the Imputation of Missing Data in Surveys with Likert-Type Scales. Journal of Classification, 28(1), 93-112. https://doi.org/10.1007/s00357-011-9074-z

- Chan, D. W. (2003). Hardiness and its role in the stress-burnout relationship among prospective Chinese teachers in Hong Kong. Teaching and Teacher Education, 19(4), 381-395. https://doi.org/10.1016/S0742-051X(03)00023-4

- Chekroud, S. R., Gueorguieva, R., Zheutlin, A. B., Paulus, M., Krumholz, H. M., Krystal, J. H., \& Chekroud, A. M. (2018). Association between physical exercise and mental health in 1-2 million individuals in the USA between 2011 and 2015: a cross-sectional study. The Lancet Psychiatry, 5(9), 739-746. https://doi.org/10.1016/S2215-0366(18)30227-X

- Choi, K. W., Chen, C.-Y., Stein, M. B., Klimentidis, Y. C., Wang, M.-J., Koenen, K. C. (2019). Assessment of Bidirectional Relationships Between Physical Activity and Depression Among Adults: A 2-Sample Mendelian Randomization Study. JAMA psychiatry, 76(4), 399-408. https://doi.org/10.1001/jamapsychiatry.2018.4175

- Cohen, J. (1988). Statistical Power Analysis for the Behavioral Sciences. New York: Routledge.

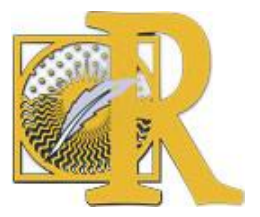

Fecha de recepción: 23-01-2021 Fecha de aceptación: 29-04-2020 Dursun, M, Emre, Y, Arı, C., Ulun, C \& Kocamaz, S. Covid-19 en Turquía: aburrimiento en el ocio, resiliencia psicológica, actividad física y estado emocional 
- Creswell, J. W., \& Creswell, J. D. (2017). Research Design: Qualitative, Quantitative, and Mixed Methods Approaches: SAGE Publications.

- Crowley, B. J., Hayslip, B., Jr., \& Hobdy, J. (2003). Psychological Hardiness and Adjustment to Life Events in Adulthood. Journal of Adult Development, 10(4), 237-248. https://doi.org/10.1023/A:1026007510134

- Dahlen, E. R., Martin, R. C., Ragan, K., \& Kuhlman, M. M. (2004). Boredom proneness in anger and aggression: effects of impulsiveness and sensation seeking. Personality and Individual Differences, 37(8), 1615-1627. https://doi.org/10.1016/i.paid.2004.02.016

- DePaolo, C. A., \& Wilkinson, K. (2014). Get Your Head into the Clouds: Using Word Clouds for Analyzing Qualitative Assessment Data. TechTrends, 58(3), 38-44. https://doi.org/10.1007/s11528-014-0750-9

- DiGiovanni, C., Conley, J., Chiu, D., \& Zaborski, J. (2004). Factors Influencing Compliance with Quarantine in Toronto During the 2003 SARS Outbreak. Biosecurity and Bioterrorism: Biodefense Strategy, Practice, and Science, 2(4), 265-272. https://doi.org/10.1089/bsp.2004.2.265

- Downey, R. G., \& King, C. (1998). Missing data in Likert ratings: A comparison of replacement methods. J Gen Psychol, 125(2), 175-191. https://doi.org/10.1080/00221309809595542

- Fahlman, S. A., Mercer-Lynn, K. B., Flora, D. B., \& Eastwood, J. D. (2013). Development and Validation of the Multidimensional State Boredom Scale. Assessment, 20(1), 68-85. https://doi.org/10.1177/1073191111421303

- Farrar, D. E., \& Glauber, R. R. (1967). Multicollinearity in Regression Analysis: The Problem Revisited. The Review of Economics and Statistics, 49(1), 92-107. https://doi.org/10.2307/1937887

- Fraenkel, J. R., Wallen, N. E., \& Hyun, H. H. (2012). How to Design and Evaluate Research in Education (8th Edition): New York: McGraw-Hill.

- Fronza, I., Janes, A., Sillitti, A., Succi, G., \& Trebeschi, S. (2013, 25-25 May 2013). Cooperation wordle using pre-attentive processing techniques. Paper presented at the 2013 6th International Workshop on Cooperative and Human Aspects of Software Engineering (CHASE).

- Frühauf, A., Schnitzer, M., Schobersberger, W., Weiss, G., \& Kopp, M. (2020). Jogging, nordic walking and going for a walk-interdisciplinary recommendations to keep people physically active in times of the covid-19 lockdown in Tyrol, Austria. Current Issues in Sport Science (CISS). https://doi.org/10.15203/CISS 2020.100

- Gatab, T. A., \& Ghajari, A. V. (2013). 2905 - Comparison of psychological hardiness with mental health among male \& female students. European Psychiatry, 28(1). https://doi.org/10.1016/S0924-9338(13)77464-9

- Gerber, M., \& Pühse, U. (2009). Review article: do exercise and fitness protect against stress-induced health complaints? A review of the literature. Scand J Public Health, 37(8), 801-819. https://doi.org/10.1177\%2F1403494809350522

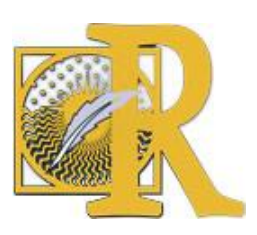

Fecha de recepción: 23-01-2021 Fecha de aceptación: 29-04-2020 Dursun, M, Emre, Y, Arı, C., Ulun, C \& Kocamaz, S. Covid-19 en Turquía: aburrimiento en el ocio, resiliencia psicológica, actividad física y estado emocional 
- Giacobbi, P. R., Hausenblas, H. A., \& Frye, N. (2005). A naturalistic assessment of the relationship between personality, daily life events, leisure-time exercise, and mood. $\begin{array}{llll}\text { Psychology of Sport and 6xercise, 6(1), } & \text { 67-81. }\end{array}$ https://doi.org/10.1016/j.psychsport.2003.10.009

- Godbey, G. (1994). Leisure in Your Life: An Exploration: Venture.

- Goldberg, Y. K., Eastwood, J. D., Laguardia, J., \& Danckert, J. (2011). Boredom: An emotional experience distinct from apathy, anhedonia, or depression. Journal of Social and Clinical Psychology, 30(6), 647-666. https://doi.org/10.1521/jscp.2011.30.6.647

- Gravetter, F. J., \& Forzano, L.-A. B. (2012). Research methods for the behavioral sciences: Cengage Learning.

- Halder, S., Mahato, A. k., \& Manot, S. (2020). COVID-19: Psychological Impact and Psychotherapeutic Intervention. EC Psychology and Psychiatry, 9(6), 32-35.

- Hammami, A., Harrabi, B., Mohr, M., \& Krustrup, P. (2020). Physical activity and coronavirus disease 2019 (COVID-19): specific recommendations for home-based physical training. Managing Sport and Leisure, 1-6. https://doi.org/10.1080/23750472.2020.1757494

- Harasymchuk, C., \& Fehr, B. (2010). A Script Analysis of Relational Boredom: Causes, Feelings, and Coping Strategies. Journal of Social and Clinical Psychology, 29(9), 9881019. https://doi.org/10.1521/jscp.2010.29.9.988

- Harris, M. B. (2000). Correlates and Characteristics of Boredom Proneness and Boredom. Journal of Applied Social Psychology, 30(3), 576-598. https://doi.org/10.1111/j.15591816.2000.tb02497.x

- Harrisson, M., Loiselle, C. G., Duquette, A., \& Semenic, S. E. (2002). Hardiness, work support and psychological distress among nursing assistants and registered nurses in Quebec. J Adv Nurs, 38(6), 584-591. https://doi.org/10.1046/j.1365-2648.2002.02225.x

- Hawryluck, L., Gold, W. L., Robinson, S., Pogorski, S., Galea, S., \& Styra, R. (2004). SARS control and psychological effects of quarantine, Toronto, Canada. Emerging infectious diseases, 10(7), 1206-1212. http://doi.org/10.3201/eid1007.030703

- Hegberg, N. J., \& Tone, E. B. (2015). Physical activity and stress resilience: Considering those at-risk for developing mental health problems. Mental Health and Physical Activity, 8, 1-7. https://doi.org/10.1016/j.mhpa.2014.10.001

- Hills, P., \& Argyle, M. (1998). Positive moods derived from leisure and their relationship to happiness and personality. Personality and Individual Differences, 25(3), 523-535. https://doi.org/10.1016/S0191-8869(98)00082-8

- Holahan, C. J., \& Moos, R. H. (1985). Life stress and health: Personality, coping, and family support in stress resistance. Journal of Personality and Social Psychology, 49(3), 739-747. https://doi.apa.org/doi/10.1037/0022-3514.49.3.739

- Hu, L.-t., \& Bentler, P. M. (1999). Cutoff criteria for fit indexes in covariance structure analysis: Conventional criteria versus new alternatives. Structural Equation Modeling, 6(1), 1-55. https://doi.org/10.1080/10705519909540118 
- Hull, R. B. (1990). Mood as a Product of Leisure: Causes and Consequences. Journal of Leisure Research, 22(2), 99-111. https://doi.org/10.1080/00222216.1990.11969818

- Hunt, C. A., Gao, J., \& Xue, L. (2014). A visual analysis of trends in the titles and keywords of top-ranked tourism journals. Current Issues in Tourism, 17(10), 849-855. https://doi.org/10.1080/13683500.2014.900000

- Iso-Ahola, S. E., \& Weissinger, E. (1987). Leisure and boredom. Journal of Social and Clinical Psychology, 5(3), 356-364. https://doi.org/10.1521/jscp.1987.5.3.356

- Iso-Ahola, S. E., \& Weissinger, E. (1990). Perceptions of Boredom in Leisure: Conceptualization, Reliability and Validity of the Leisure Boredom Scale. Journal of Leisure Research, 22(1), 1-17. https://doi.org/10.1080/00222216.1990.11969811

- Işık, Ş. (2016). Developing The Psychological Hardiness Scale: The Validity and Reliability Study. The Journal of Happiness \& Well-Being, 4(2), 165-182.

- Iwasaki, Y., Mackay, K. J., Mactavish, J. B., Ristock, J., \& Bartlett, J. (2006). Voices from the Margins: Stress, Active Living, and Leisure as a Contributor to Coping with Stress. Leisure Sciences, 28(2), 163-180. https://doi.org/10.1080/01490400500484065

- Iwasaki, Y., Zuzanek, J., \& Mannell, R. C. (2001). The effects of physically active leisure on stress-health relationships. Canadian Journal Of Public Health=Revue canadienne de sante publique, 92(3), 214-218. https://doi.org/10.1007/BF03404309

- Jalali, M., Shahabi, S., Bagheri Lankarani, K., Kamali, M., \& Mojgani, P. (2020). COVID19 and disabled people: perspectives from Iran. Disability \& Society, 35(5), 844-847. https://doi.org/10.1080/09687599.2020.1754165

- Janisse, H. C., Nedd, D., Escamilla, S., \& Nies, M. A. (2004). Physical activity, social support, and family structure as determinants of mood among European-American and African-American women. Women Health, 39(1), 101-116. https://doi.org/10.1300/J013v39n01 06

- Kara, F. M. (2019). Internet Addiction: Relationship with Perceived Freedom in Leisure, Perception of Boredom and Sensation Seeking. Higher Education Studies, 9(2), 131-140. https://doi.org/10.5539/hes.v9n2p131

- Kara, F. M., Gürbüz, B., \& Öncü, E. (2014). Leisure Boredom Scale: The Factor Structure and the Demographic Differences. Turkish Journal of Sport and Exercise, 16(2), 28-35. https://doi.org/10.15314/TJSE.201428102

- Kekäläinen, T., Freund, A. M., Sipilä, S., \& Kokko, K. (2019). Cross-Sectional and Longitudinal Associations between Leisure Time Physical Activity, Mental Well-Being and Subjective Health in Middle Adulthood. Applied Research in Quality of Life. https://doi.org/10.1007/s11482-019-09721-4

- Klaperski, S., von Dawans, B., Heinrichs, M., \& Fuchs, R. (2013). Does the level of physical exercise affect physiological and psychological responses to psychosocial stress in women? Psychology of Sport and Exercise, 14(2), 266-274. https://doi.org/10.1016/j.psychsport.2012.11.003

- Kline, R. B. (2015). Principles and practice of structural equation modeling: Guilford Publications.

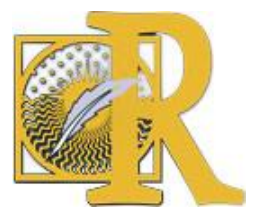

Fecha de recepción: 23-01-2021 Fecha de aceptación: 29-04-2020 
- Kobasa, S. C. (1979). Stressful life events, personality, and health: An inquiry into hardiness. Journal of Personality and Social Psychology, 37(1), 1-11. https://doi.org/10.1037/0022-3514.37.1.1

- Kobasa, S. C., Maddi, S. R., \& Kahn, S. (1982). Hardiness and health: A prospective study. Journal of Personality and Social Psychology, 42(1), 168-177. https://doi.apa.org/doi/10.1037/0022-3514.42.1.168

- Kucharski, A. J., Russell, T. W., Diamond, C., Liu, Y., Edmunds, J., Funk, S., . . Flasche, S. (2020). Early dynamics of transmission and control of COVID-19: a mathematical modelling study. The Lancet Infectious Diseases, 20(5), 553-558. https://doi.org/10.1016/S1473-3099(20)30144-4

- Lambert, C. E., Jr., \& Lambert, V. A. (1999). Psychological hardiness: state of the science. Holist Nurs Pract, 13(3), 11-19. https://doi.org/10.1097/00004650-199904000-00004

- Lau, J. T., Yang, X., Tsui, H., \& Kim, J. H. (2003). Monitoring community responses to the SARS epidemic in Hong Kong: from day 10 to day 62. J Epidemiol Community Health, 57(11), 864-870. http://dx.doi.org/10.1136/jech.57.11.864

- Lee, S., Chan, L. Y. Y., Chau, A. M. Y., Kwok, K. P. S., \& Kleinman, A. (2005). The experience of SARS-related stigma at Amoy Gardens. Social Science \& Medicine, 61(9), 2038-2046. https://doi.org/10.1016/j.socscimed.2005.04.010

- Lee, Y. G., \& Bhargava, V. (2004). Leisure Time: Do Married and Single Individuals Spend It Differently? Family and Consumer Sciences Research Journal, 32(3), 254-274. https://doi.org/10.1177/1077727X03261631

- LePera, N. (2011). Relationships between boredom proneness, mindfulness, anxiety, depression, and substance use. The New School Psychology Bulletin, 8(2), 15-25.

- Lippi, G., Henry, B. M., \& Sanchis-Gomar, F. (2020). Physical inactivity and cardiovascular disease at the time of coronavirus disease 2019 (COVID-19). European Journal of Preventive Cardiology, O(0), 2047487320916823. https://doi.org/10.1177\%2F2047487320916823

- Lu, H., Stratton, C. W., \& Tang, Y.-W. (2020). Outbreak of pneumonia of unknown etiology in Wuhan, China: The mystery and the miracle. Journal of Medical Virology, 92(4), 401402. https://doi.org/10.1002/jmv.25678

- Maddi, S. R., Harvey, R. H., Khoshaba, D. M., Lu, J. L., Persico, M., \& Brow, M. (2006). The personality construct of hardiness, III: Relationships with repression, innovativeness, authoritarianism, and performance. J Pers, 74(2), 575-597. https://doi.org/10.1111/i.14676494.2006.00385.x

- Mandolesi, L., Polverino, A., Montuori, S., Foti, F., Ferraioli, G., Sorrentino, P., \& Sorrentino, G. (2018). Effects of Physical Exercise on Cognitive Functioning and Wellbeing: Biological and Psychological Benefits. Frontiers in Psychology, 9(509). https://doi.org/10.3389/fpsyg.2018.00509

- Marafa, L. M., \& Tung, F. (2004). Changes in Participation in Leisure and Outdoor Recreation Activities Among Hong Kong People during the SARS outbreak. World Leisure Journal, 46(2), 38-47. https://doi.org/10.1080/04419057.2004.9674356 
- Matias, T., Dominski, F. H., \& Marks, D. F. (2020). Human needs in COVID-19 isolation. Journal of Health Psychology, 25(7), 871-882. https://doi.org/10.1177\%2F1359105320925149

- Maunder, R., Hunter, J., Vincent, L., Bennett, J., Peladeau, N., Leszcz, M., . . Mazzulli, T. (2003). The immediate psychological and occupational impact of the 2003 SARS outbreak in a teaching hospital. CMAJ : Canadian Medical Association journal=journal de l'Association medicale canadienne, 168(10), 1245-1251. Retrieved from https://pubmed.ncbi.nlm.nih.gov/12743065

- Mikulas, W. L., \& Vodanovich, S. J. (1993). The essence of boredom. The Psychological Record, 43(1), 3-12.

- Min, J.-A., Yoon, S., Lee, C.-U., Chae, J.-H., Lee, C., Song, K.-Y., \& Kim, T.-S. (2013). Psychological resilience contributes to low emotional distress in cancer patients. Supportive Care in Cancer, 21(9), 2469-2476. https://doi.org/10.1007/s00520-013-1807-6

- Muscogiuri, G., Barrea, L., Savastano, S., \& Colao, A. (2020). Nutritional recommendations for CoVID-19 quarantine. European Journal of Clinical Nutrition. https://doi.org/10.1038/s41430-020-0635-2

- Muthen, B. O. (2001). Latent Variable Mixture Modeling. In G. A. Marcoulides \& R. E. Schumacker (Eds.), New Developments and Techniques in Structural Equation Modeling (pp. 1-33). London: Lawrence Erlbaum Associates.

- Newberry, A. L., \& Duncan, R. D. (2001). Roles of Boredom and Life Goals in Juvenile Delinquency. Journal of Applied Social Psychology, 31(3), 527-541. https://doi.org/10.1111/j.1559-1816.2001.tb02054.x

- O'Hanlon, J. F. (1981). Boredom: Practical consequences and a theory. Acta Psychologica, 49(1), 53-82. https://doi.org/10.1016/0001-6918(81)90033-0

- Oh, S.-S., Caldwell, L. L., \& Oh, S.-Y. (2001). An Examination of Leisure Constraints, Participation in Creative Activities and Hobbies, and Leisure Boredom in a Sample of Korean Adults. World Leisure Journal, 43(2), 30-38. https://doi.org/10.1080/04419057.2001.9674228

- Ong, A. D., Bergeman, C. S., Bisconti, T. L., \& Wallace, K. A. (2006). Psychological resilience, positive emotions, and successful adaptation to stress in later life. J Pers Soc Psychol, 91(4), 730-749. https://doi.apa.org/doi/10.1037/0022-3514.91.4.730

- Pearson, Q. M. (1998). Job Satisfaction, Leisure Satisfaction, and Psychological Health. The Career Development Quarterly, 46(4), 416-426. https://doi.org/10.1002/j.21610045.1998.tb00718.x

- Penedo, F. J., \& Dahn, J. R. (2005). Exercise and well-being: a review of mental and physical health benefits associated with physical activity. Current Opinion in Psychiatry, 18(2), 189-193. Retrieved from https://journals.Iww.com/copsychiatry/Fulltext/2005/03000/Exercise and well being a review of mental and.13. aspx

- Pfefferbaum, B., \& North, C. S. (2020). Mental Health and the Covid-19 Pandemic. N Engl $J$ Med. https://doi.org/10.1056/neimp2008017

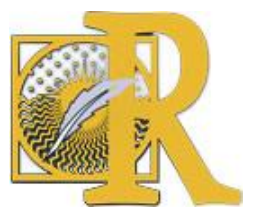

Fecha de recepción: 23-01-2021 Fecha de aceptación: 29-04-2020 
- Philippe, F. L., Lecours, S., \& Beaulieu-Pelletier, G. (2009). Resilience and positive emotions: examining the role of emotional memories. $J$ Pers, 77(1), 139-175. https://doi.org/10.1111/j.1467-6494.2008.00541.x

- Plutchik, R. (1980). A General Psychoevolutionary Theory of Emotion. In R. Plutchik \& H. Kellerman (Eds.), Theories of Emotion (pp. 3-33): Academic Press. https://doi.org/10.1016/B978-0-12-558701-3.50007-7

- Rodrigues, F., Teixeira, D. S., Cid, L., \& Monteiro, D. (2019). Have you been exercising lately? Testing the role of past behavior on exercise adherence. Journal of Health Psychology, O(0), 1359105319878243. https://doi.org/10.1177\%2F1359105319878243

- Rodríguez, M. Á., Crespo, I., \& Olmedillas, H. (2020). Exercising in times of COVID-19: what do experts recommend doing within four walls? Revista Española de Cardiología (English Edition). https://doi.org/10.1016/j.rec.2020.04.001

- Rudwan, S., \& Alhashimia, S. (2018). The Relationship between Resilience \& Mental Health among a Sample of University of Nizwa Students - Sultanate of Oman. European Scientific Journal, 14(2), 288-303. https://doi.org/10.19044/esj.2018.v14n2p288

- Rupp, D. E., \& Vodanovich, S. J. (1997). The role of boredom proneness in self-reported anger and aggression. Journal of Social Behavior \& Personality, 12(4), 925-936.

- Sato, M., Jordan, J. S., \& Funk, D. C. (2014). The Role of Physically Active Leisure for Enhancing Quality of Life. Leisure Sciences, 36(3), 293-313. https://doi.org/10.1080/01490400.2014.886912

- Schuch, F. B., Vancampfort, D., Firth, J., Rosenbaum, S., Ward, P. B., Silva, E. S. Stubbs, B. (2018). Physical Activity and Incident Depression: A Meta-Analysis of Prospective $\begin{array}{llll}\text { Cohort Studies. } A m ~ & J & \text { Psychiatry, 175(7), 631-648. }\end{array}$ https://doi.org/10.1176/appi.ajp.2018.17111194

- Schwartz, G. M., \& Campagna, J. (2008). New meaning for the emotional state of the elderly, from a leisure standpoint. Leisure Studies, 27(2), 207-211. https://doi.org/10.1080/02614360801902232

- Searle, M. S., \& Jackson, E. L. (1985). Socioeconomic variations in perceived barriers to recreation participation among would-be participants. Leisure Sciences, 7(2), 227-249. https://doi.org/10.1080/01490408509512120

- Shaw, S. M. (1994). Gender, Leisure, and Constraint: Towards a Framework for the Analysis of Women's Leisure. Journal of Leisure Research, 26(1), 8-22. https://doi.org/10.1080/00222216.1994.11969941

- Shaw, S. M., Caldwell, L. L., \& Kleiber, D. A. (1996). Boredom, Stress and Social Control in the Daily Activities of Adolescents. Journal of Leisure Research, 28(4), 274-292. https://doi.org/10.1080/00222216.1996.11949776

- Sinclair, R. R., \& Tetrick, L. E. (2000). Implications of Item Wording for Hardiness Structure, Relation with Neuroticism, and Stress Buffering. Journal of Research in Personality, 34(1), 1-25. https://doi.org/10.1006/irpe.1999.2265 
- Skues, J., Williams, B., Oldmeadow, J., \& Wise, L. (2016). The Effects of Boredom, Loneliness, and Distress Tolerance on Problem Internet Use Among University Students. International Journal of Mental Health and Addiction, 14(2), 167-180. https://doi.org/10.1007/s11469-015-9568-8

- Smith, R. P. (1981). Boredom: A Review. Human Factors: The Journal of the Human $\begin{array}{llll}\text { Factors and Ergonomics 329-340. } & \text { Society, }\end{array}$ https://doi.org/10.1177/001872088102300308

- Sohrabi, C., Alsafi, Z., O'Neill, N., Khan, M., Kerwan, A., Al-Jabir, A., Agha, R. (2020). World Health Organization declares global emergency: A review of the 2019 novel coronavirus (COVID-19). International Journal of Surgery, 76, 71-76. https://doi.org/10.1016/.i.jsu.2020.02.034

- Spalding, T. W., Lyon, L. A., Steel, D. H., \& Hatfield, B. D. (2004). Aerobic exercise training and cardiovascular reactivity to psychological stress in sedentary young normotensive men and women. Psychophysiology, 41(4), 552-562. https://doi.org/10.1111/j.14698986.2004.00184.x

- Steiger, J. H. (2000). Point Estimation, Hypothesis Testing, and Interval Estimation Using the RMSEA: Some Comments and a Reply to Hayduk and Glaser. Structural Equation Modeling: $\quad$ A Multidisciplinary Journal, $\quad 7(2), \quad$ 149-162. https://doi.org/10.1207/S15328007SEM0702 1

- Tabachnick, B. G., \& Fidell, L. S. (2013). Using Multivariate Statistics (6th ed.): Pearson.

- Thompson, B. (2004). Exploratory and confirmatory factor analysis: Understanding concepts and applications. Washington, DC, US: American Psychological Association.

- Torkildsen, G. (2005). Leisure and Recreation Management Routledge.

- Tugade, M. M., Fredrickson, B. L., \& Barrett, L. F. (2004). Psychological resilience and positive emotional granularity: examining the benefits of positive emotions on coping and health. Journal of personality, 72(6), 1161-1190. https://doi.org/10.1111/j.14676494.2004.00294.x

- Vodanovich, S. J. (2003). Psychometric measures of boredom: a review of the literature. J Psychol, 137(6), 569-595. https://doi.org/10.1080/00223980309600636

- Vodanovich, S. J., \& Watt, J. D. (1999). The relationship between time structure and boredom proneness: An investigation within two cultures. The Journal of Social Psychology, 139(2), 143-152. https://doi.org/10.1080/00224549909598368

- Watt, J. D., \& Davis, F. E. (1991). The prevalence of boredom proneness and depression among profoundly deaf residential school adolescents. American Annals of the Deaf, 136(5), 409-413. https://doi.org/10.1353/aad.2012.0470

- Wegner, L., \& Flisher, A. J. (2009). Leisure boredom and adolescent risk behaviour: a systematic literature review. J Child Adolesc Ment Health, 21(1), 1-28. https://doi.org/10.2989/JCAMH.2009.21.1.4.806

- Wegner, L., Flisher, A. J., Chikobvu, P., Lombard, C., \& King, G. (2008). Leisure boredom and high school dropout in Cape Town, South Africa. Journal of Adolescence, 31(3), 421431. https://doi.org/10.1016/..adolescence.2007.09.004 
- Williams, W., Parkes, E. L., \& Davies, P. (2013). Wordle: A method for analysing MBA student induction experience. The International Journal of Management Education, 11(1), 44-53. https://doi.org/10.1016/j.ijme.2012.10.002

- World Health Organization. (2020a). Coronavirus disease (COVID-19) Pandemic. Retrieved from https://www.who.int/emergencies/diseases/novel-coronavirus-2019

- World Health Organization. (2020b). WHO Coronavirus Disease (COVID-19) Dashboard. Retrieved from https://covid19.who.int/

- World Health Organization. (2020c). WHO Director-General's opening remarks at the media briefing on COVID-19 - 11 March 2020. Retrieved from https://www.who.int/dg/speeches/detail/who-director-general-s-opening-remarks-at-themedia-briefing-on-covid-19---11-march-2020

- Zhang, Y., \& Ma, Z. F. (2020). Impact of the COVID-19 Pandemic on Mental Health and Quality of Life among Local Residents in Liaoning Province, China: A Cross-Sectional Study. International Journal of Environmental Research and Public Health, 17(7), 2381. Retrieved from https://www.mdpi.com/1660-4601/17/7/2381 